九州大学学術情報リポジトリ

Kyushu University Institutional Repository

Water mass conditions during the past 11,000 years in the innermost part of the Kagoshima Bay, South Kyushu, Japan : evidence from the fossil shell assemblages, oxygen and carbon isotopic compositions

Kameyama, Sohiko

National Institute for Environmental Studies

Shimoyama, Shoichi

Department of Earth and Planetary Sciences, Graduate school of Sciences, Kyushu University

Miyabe, Shunsuke

Marine Works Japan

Yamanaka, Toshiro

Department of Earth Science, Graduate school of Natural Science and Technology, Okayama University

https://doi.org/10.5109/11814

出版情報: 九州大学大学院理学研究院紀要 : Series D, Earth and planetary sciences. 32 (1)， pp.97-112, 2008-02-01. Faculty of Science, Kyushu University

バージョン :

権利関係 : 
Mem. Fac. Sci., Kyushu Univ., Ser. D, Earth \& Planet. Sci., Vol. XXXII, No. 1, pp. 97-112, February 1, 2008

\title{
Water mass conditions during the past 11,000 years in the innermost part of the Kagoshima Bay, South Kyushu, Japan: evidence from the fossil shell assemblages, oxygen and carbon isotopic compositions
}

Sohiko Kameyama*, Shoichi Shimoyama ${ }^{* *}$, Shunsuke Miyabe ${ }^{* * *}$ and Toshiro Yamanaka***

\begin{abstract}
Quantitative analysis of fossil shell assemblage was carried out in Shinjima Island located in the innermost part of the Kagoshima Bay, South Kyushu, to confirm the change of mollusks' habitat conditions. In addition, stable carbon and oxygen isotopic ratios of carbonate fossil shells were also measured to clarify the water-mass conditions of the Kagoshima Bay during the past 11,000 years. Both the fossil shell community and carbon isotopic ratios clearly indicate that the water-masses in the innermost part of the Kagoshima Bay were influenced strongly by the pelagic water, which replaced the fresh water mass initially present in the paleo-caldera lake. Thus, the pelagic water mass increased progressively, and became the maximum during the period between 6,000-2,300 yrs BP when the shell bed (Moeshima Shell Bed) was formed. The analysis of fossil shell assemblage and shell size distribution, however, indicates that the Neopycnodonte cochlear, the dominant species in the Moeshima Shell Bed, did not reproduce in the bay, but supplied as the planktonic larvae from the pelagic water mass. After that, it started that the influence of pelagic water-mass became to be weak at 2,300 yrs BP, when the supply of the larvae was stopped. As a result, the dominant pelagic species disappeared from the innermost part of the Kagoshima Bay, and consequently the shell community was replaced by the assemblage comprised of the inner bay species. Such a change in mollusks community appears to be depended on the time-series variation of the Kuroshio Current influence.
\end{abstract}

Keywords: fossil shell assemblage, oxygen isotope, carbon isotope, Holocene, water mass condition, Shinjima, Kagoshima Bay

\section{Introduction}

The Kagoshima Bay is a deep bay including some submerged calderas (Fig. 1). The innermost part of the bay lies on Aira Caldera created by Ito eruption at 25,000 yrs BP (Matsumoto, 1943; Machida and Arai, 1992). The mean water-depth of the innermost part is about $140 \mathrm{~m}$. A new small

Manuscript received on 16 September 2007; accepted on 27 September 2007

* National Institute for Environmental Studies, 16-2, Onogawa, Tsukuba, Ibaraki 305-8506, JAPAN; kameyama.sohiko@nies.go.jp

** Department of Earth and Planetary Sciences, Graduate school of Sciences, Kyushu University. 6-10-1, Hakozaki, Fukuoka 812-8581 JAPAN

*** Marine Works Japan. LTD, 2-16-32, Kamariya-higashi, Kanazawa-ku, Yokohama 236-0042, JAPAN

${ }^{* * * *}$ Department of Earth Science, Graduate school of Natural Science and Technology, Okayama University. 3-1-1, Tsushima-Naka, Okayama 701-8530, JAPAN 
submarine caldera, Wakamiko Caldera, is located in the eastern part of the innermost part of the bay (Fig. 1), and it is still active (Yamanaka et al., 1999). It is suggested that the Aira Caldera had been filled with fresh water during the global low sea level stand at least until 15,000 yrs BP (Oki, 2000). The water-mass in the caldera lake changed from fresh water to seawater at about 11,000 yrs BP in response to rapid global sea-level rise during the period of 15,000-8,000 yrs BP (Kameyama et al., 2005). After that, sea level has been stable for the past 2,000 years. During the late Holocene many molluscan species, which were different from the modern assemblage, inhabited there. Lunulicardia retusa was the dominant species during the late Holocene. Today this taxon is known as a subtropical pelagic species, and it inhabits in shallow sea water regions south of Amami Islands (about $28^{\circ} \mathrm{N}$ ) (Higo et al., 1999). Lunulicardia retusa, however, appeared at the entrance and in the middle parts of the Kagoshima Bay only during about 6,000-2,000 yrs BP (Oki, 2000). Little is known on the prosperity and the abrupt extinction of Lunulicardia retusa.

Shinjima Island is located in the innermost part of the Kagoshima Bay (Fig. 1). It emerged from the sea floor at 230 years ago accompanied by the volcanic activity. Therefore, it is possible that the marine section of the Shinjima can be correlated with the sediments deposited on the past sea floor in the innermost part of the Kagoshima Bay. Thus, Shinjima provides a suitable field to study the paleoenvironmental changes in the innermost part of the Kagoshima Bay. Highly concentrated fossil shell bed in Shinjima, referred as the Moeshima Shell Bed, is formed between 6,000-2,000 yrs BP. The fossil community lacks the inner bay species, but includes the dominant pelagic species (Shuto, 1962; Hirata, 1964). Such a faunal composition suggests that the pelagic environment was present in the innermost part of the bay, in contrast to the neritic environment there today. Nevertheless, little paleontological investigation relevant to the environmental change has been conducted thus far.

Therefore, the analysis of fossil community on Shinjima Island has been carried out to clarify the paleoenvironmental change in the innermost part of the Kagoshima Bay. Furthermore, stable isotopic ratios of carbon and oxygen in carbonate shells, oxygen of $\mathrm{H}_{2} \mathrm{O}$ and carbon of dissolved inorganic carbonate in seawater were also measured to compare with the results of fossil community analysis.

\section{Study area and experimental method}

\subsection{Geology of Shinjima Island}

The Kagoshima Bay lies on a volcanic front of the southwestern Japan, where several calderas form a line from the north to the south (Fig. 1). The maximum depth of the bay is $206 \mathrm{~m}$ and the mean depth is $140 \mathrm{~m}$. The mouth of the bay opens to the East China Sea. The innermost part of the bay is the flooded Aira caldera, which was formed by a large eruption at about 25,000 yrs BP. Shinjima Island is located northeast of the presently active Sakurajima volcano, standing on the edge of the Aira caldera (Fig. 1).

According to Kuwashiro et al. (1970), Shinjima Island was once a part of the sea floor of the Kagoshima Bay, and emerged at An-ei eruption during April to September 1780. The island is separated into several blocks by normal faults in east-west direction. These faults were formed during the rifting of Shinjima (Kuwashiro et al., 1970). The central block is topographically lower than the north and south blocks in Shinjima. The northern margin of the island represents a wavecut sheer cliff, and the south block tilts gently to the south, and a small sand spit pushes out into the sea at the southern point (Fig. 2).

Regarding the stratigraphy of Shinjima, there has been a discrepancy in opinion among the several previous works (Yamaguchi, 1915; Shikama, 1955; Kano et al., 1996; Okuno et al., 1998). Based on ${ }^{14} \mathrm{C}$ and fission track dating methods (Kameyama et al., 2005), a revised stratigraphy from 


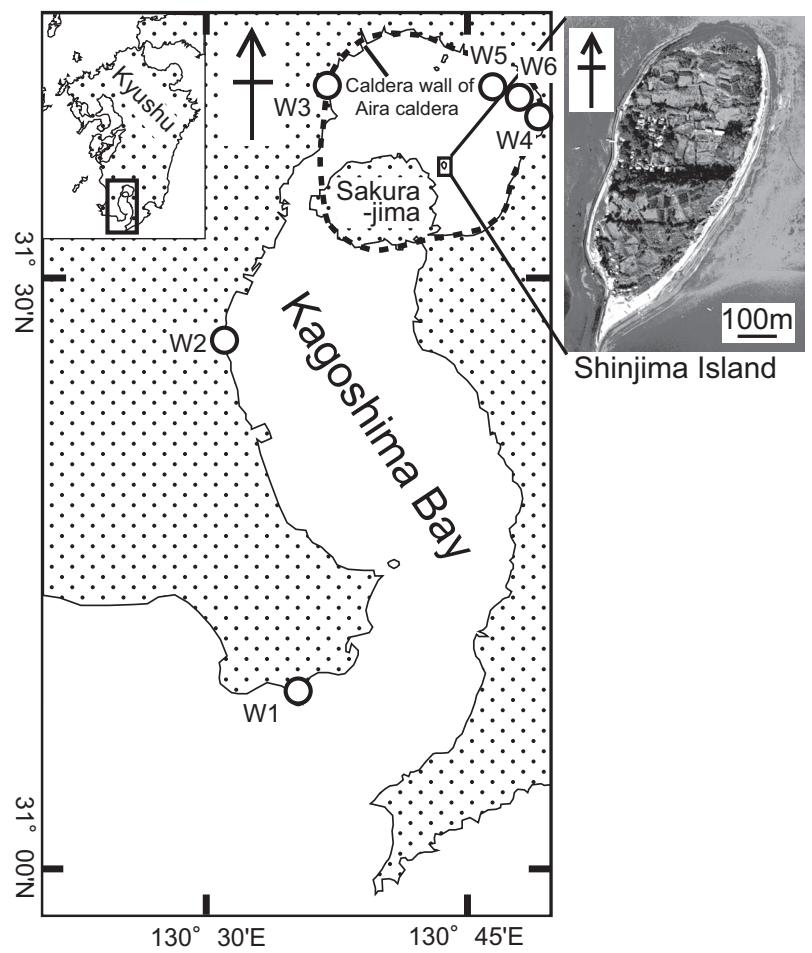

Fig. 1. Study area and aerial photograph of Sinjima (Moeshima) Island. W1 to W6 indicate the locations of water sample for measurements of isotopic composition of inorganic carbonate. W1 to W4 samples were taken at beach. W5 and W6 samples were obtained from $70 \mathrm{~m}$ and $50 \mathrm{~m}$ depth in the NT05-01 cruise.

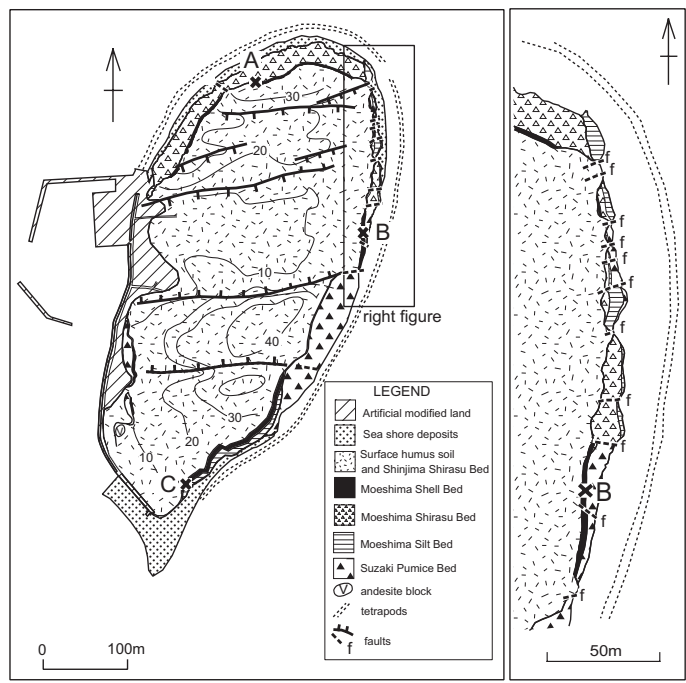

Fig. 2. Geological map of Shinjima Island (after Kameyama et al., 2005).

B indicates the sampling location of the Moeshima Shell Bed in this study. 


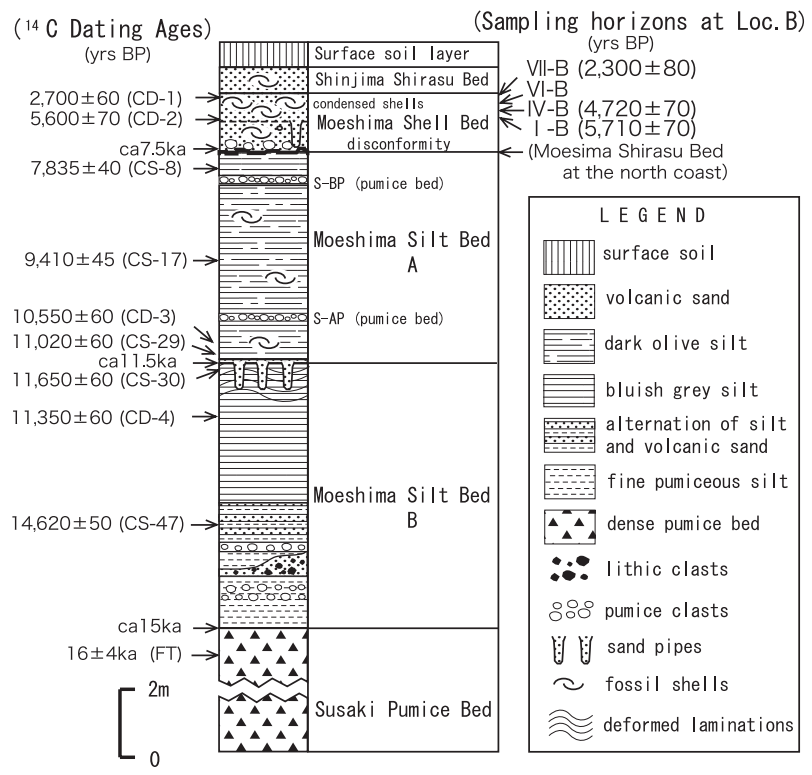

Fig. 3. Geological column of Shinjima Island, modified from Kameyama et al., (2005). I, IV, VI and VI- B are the horizons for balk samples.

the base to top was proposed as follows: the Susaki Pumice Bed, Moeshima Silt Bed, Moeshima Sirasu Bed, Moeshima Shell Bed, and Shinjima Sirasu Bed (Figs. 2-3).

The Moeshima Shell Bed is about $1 \mathrm{~m}$ in thickness and lies broadly in the upper part of Shinjima Island. This bed consists of well preserved fossil shells and coarse pumice debris derived from Sakurajima Island. According to the ${ }^{14} \mathrm{C}$ dating, Okuno et al. (1998) and Kameyama et al. (2005) concluded that this fossil shell bed was formed during 6,000-2300 yrs BP. The most dominant mollusks species in the Moeshima Shell Bed is Neopycnodonte cochlear, and this species grows in colonies (Shikama, 1955; Shuto, 1962; Hirata, 1964: Fig. 4). Over 100 pelagic species, Serpulorbis xenophorus, Xenophora pallidula and Cryptopecten cesiculosus were also found (Shikama, 1955; Shuto, 1962; Hirata, 1964).

\subsection{Analyses of fossil shell assemblage in Shinjima Island}

The bulk sampling of sediments is standardized to the volume $(25 \mathrm{~cm} \times 25 \mathrm{~cm} \times 25 \mathrm{~cm}$, a cube) and the sieve screen ( $2 \mathrm{~mm}$ mesh). The bulk sampling from three horizons was carried out at an outcrop of Locality B in the Moeshima Shell Bed (Fig. 4). For the shells of each species in each of the bulk unit, numbers of valves in the following categories were counted: complete left (CL); damaged left (DL); complete right (CR); and damaged right (DR). The number of individuals (N), where $\mathrm{N}$ is the largest value between the number of left $(\mathrm{CL}+\mathrm{DL})$ and that of the total right $(\mathrm{CR}+\mathrm{DR})$ valves, were also recorded. Complete shells of Neopycnodonte cochlear, which is the most dominant species in the Moeshima Shell Bed, were measured for the shell height to ascertain the size frequency distribution and dynamics of juvenile and adult shells in the fossil community.

\subsection{Measurements of carbon and oxygen isotopic ratios and mineral formation of carbonate shells}

Neopycnodonte cochlear, Cryptopecten cesiculosus and Zeuxi hayashii were collected from 


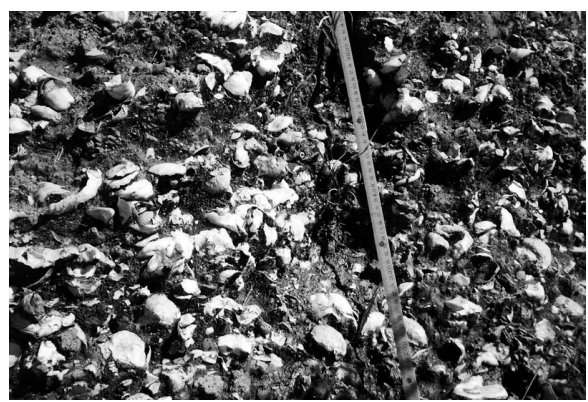

Fig. 4. Outcrop of the Moeshima Shell Bed at locality B in Fig. 2. Most of the fossil shells are Neopycnodonte cochlear, and the scale length is $45 \mathrm{~cm}$.

three levels (B-I: 5,710 \pm 70 , B-IV: 4,720 \pm 70 and B- VII: $2,300 \pm 80 \mathrm{yrs}$ BP) in the Moeshima Shell Bed at Locality B (Fig. 2). Paphia amabilis was taken at one level (B-II : 10,550 $\pm 40-5,710 \pm 70$ yrs BP) in Moeshima Shell Bed at point B and another level (10,550 40 yrs BP) in Moeshima Silt Bed at Locality C in Fig. 2. Furthermore, Saccostrea echinata and Monodonta labio were taken from the concrete tetrapods located on the beach of Shinjima Island in order to compare the present species with the extant species.

The surface of each shell sample was carefully removed by hand polishing and rinsed with diluted acetic acid. Then, the cleaned shell samples were crushed into fine grains in an agate mortar with a pestle. The carbonate powder was reacted with $100 \%$ phosphoric acid in pre-evacuated reaction tube at $25.0 \pm 0.2^{\circ} \mathrm{C}$ to convert into carbon dioxide in vacuo. After dehydration, carbon dioxide gas was analyzed for carbon and oxygen isotopic ratio on an isotope mass spectrometer (IRMS) (VG, PRISM). Measurements were made twice on each sample. The isotopic compositions were reported as $\delta^{13} \mathrm{C}, \delta^{18} \mathrm{O}$ in per mil (\%) variation, based on the divergence from the V-PDB standard (Craig, 1957; Coplen, 1994). Analytical precision was $\pm 0.05 \%$ for both carbon and oxygen isotopic measurements.

Mineralogical characterization of the carbonate shells was carried out by X-ray diffractometry based on the method of $\mathrm{Cu}-\mathrm{Ka}$ radiation (Table 1). Major three spectra (20.95, 22.85, and $30.35 \mathrm{~nm}$ for calcite; $2.702,3.397$, and $19.77 \mathrm{~nm}$ for aragonite) were used for the mineral identification.

Table 1. List of molluscan fossil shells in the Moeshima Shell Bed. I, IV and VII- B are the bulk samples. Numerical values show individual numbers of fossil shells in a bulk sample unite $(25 \mathrm{~cm} \times 25 \mathrm{~cm} \times 10 \mathrm{~cm}$ in depth).

\begin{tabular}{lrrrr}
\hline & $2,300 \pm 80$ yrs BP & $4,720 \pm 70$ yrs BP & $5,710 \pm 70$ yrs BP Carbonate \\
& VII-B & IV-B & I-B & type \\
\hline Neopycnodonte cochlear & 293 & 2,535 & 1,273 & calcite \\
Striarca fausta & 4 & 141 & 100 & \\
Cryptopecten vesiculosus & 17 & 111 & 46 & calcite \\
Chlamys lemniscata & 5 & 66 & 36 & \\
Varicorbula modesta & 0 & 33 & 14 & \\
Cardita leana & 2 & 21 & 13 & \\
other bivalves(28 species) & 6 & 100 & 81 & \\
Zeuxis hayashii & 3 & 41 & 29 & aragonite \\
Natica nipponensis & 0 & 22 & 15 & \\
Horaicalavus shitoensis & 0 & 19 & 1 & \\
other spiral shells(42 species) & 11 & 109 & 64 & \\
Total & 341 & 3,198 & 1,672 & \\
\hline
\end{tabular}




\subsection{Isotopic measurements of $\mathrm{H}_{2} \mathrm{O}$ and dissolved inorganic carbonate in seawater}

Seawater samples were taken from both the surface and at $200 \mathrm{~m}$ depth of the water column in the innermost part of the Kagoshima Bay (W5 in Fig. 1; 31 ${ }^{\circ} 39.749^{\prime} \mathrm{N}, 130^{\circ} 46.290^{\prime} \mathrm{E}$ ) during the Cruise NT05-01 of R/V Natsushima to measure the oxygen isotopic composition of $\mathrm{H}_{2} \mathrm{O}$ molecules. According to the conventional method described in Epstein and Mayeda (1953), the sea water samples were introduced into the equilibrators and these head-space were permuted with $\mathrm{CO}_{2}$ gas in which isotopic composition was decided and shaken until reaching isotopic equilibrium between oxygen of liquid water and $\mathrm{CO}_{2}$ gas. Then, $\mathrm{CO}_{2}$ in gas phase was introduced to the same IR-MS system to measure the oxygen isotopic ratios. Analytical precision in this measurement system was $\pm 0.1 \%$ for oxygen isotopic composition.

Furthermore, surface seawater samples were taken at six locations in the Kagoshima Bay (W1W6 in Fig. 1) to measure the carbon isotopic ratios of the dissolved inorganic carbonate. The water samples were immediately sterilized after recovered by addition of saturated $\mathrm{HgCl}_{2}$ solution to avoid the degeneration. After the acidification of the samples with sulfamic acid, discharged inorganic $\mathrm{CO}_{2}$ was introduced into IR-MS (Finnigan, MAT252). Analytical precision in this measurement system was $\pm 0.1 \%$ for carbon isotopic composition.

\section{Results and discussion}

\subsection{Fossil shell assemblages in Shinjima Island}

Marine condition of the Aira caldera initiated since about 11,000 yrs BP, as shown by the base of the upper member of the Moeshima Silt Bed (Kameyama et al., 2005). The fossil shell assemblage in this horizon contains of mainly three dominant species: Paphia amabilis, Keenaea samarangae, and Lucinoma annulatum. The ${ }^{14} \mathrm{C}$ age of a shell of Paphia amabilis is 10,550 yrs BP (Kameyama et al., 2005). The bivalve shells are less concentrated than in other horizons, but they are considered as autochthonous fossils. Because the articulated shells are in high proportion without reworking. Most of the molluscan species in the upper member of the Moeshima Silt Bed are pelagic ones (Higo et al., 1999). This indicates that the pelagic assemblages appeared in the inner most area of the Kagoshima Bay without the inner bay species present when the water conditions in the innermost area of the bay had changed from fresh water into marine.

Deep-sea oyster, Neopycnodonte cochlear, attains over $80 \%$ (Table 1; Fig. 5) of the population in the assemblages of the three bulk samples collected from the Moeshima Shell Bed. Other major bivalve species are Striarca fausta, Cryptopecten vesiculosus, Chlamys lemniscata, Varicorbula modesta, and Cardita leana (Fig. 5). The sum of Neopycnodonte cochlear and seven major bivalve species exceeds to $90 \%$ of the assemblage. Snail shells, such as Zeuxis hayashii and Natica nipponensis, and crabs were collected also from the Moeshima Shell Bed. However, the ratios in snail shell are very low in comparison with the bivalve. Hence, the resulting contribution by snail shells and other fossils to the whole assemblages of the Moeshima Shell Bed is very small.

This community structure is very simple, so that it is regarded as the inner bay assemblages rather than the pelagic assemblages (Raup and Stanley, 1978). However, most of the species in the Moeshima Shell Bed has been considered as the pelagic assemblage (Higo et al., 1999). As a characteristic and common to all the species, their habitat depths are deeper than $100 \mathrm{~m}$.

Neopycnodonte cochlear is the most dominant species. It is an epifaunal oyster, and is adhesive on shell fragment or granule with left valves on pelagic sea floor greater than $100 \mathrm{~m}$ depth today. This species is strongly adapted in most part of the Kagoshima Bay where the maximum depth is about $200 \mathrm{~m}$ and the bottom materials are rich in andesite grains derived from Sakurajima volcano. In most cases, the individuals of Neopycnodonte cochlear have been found as living positions with 


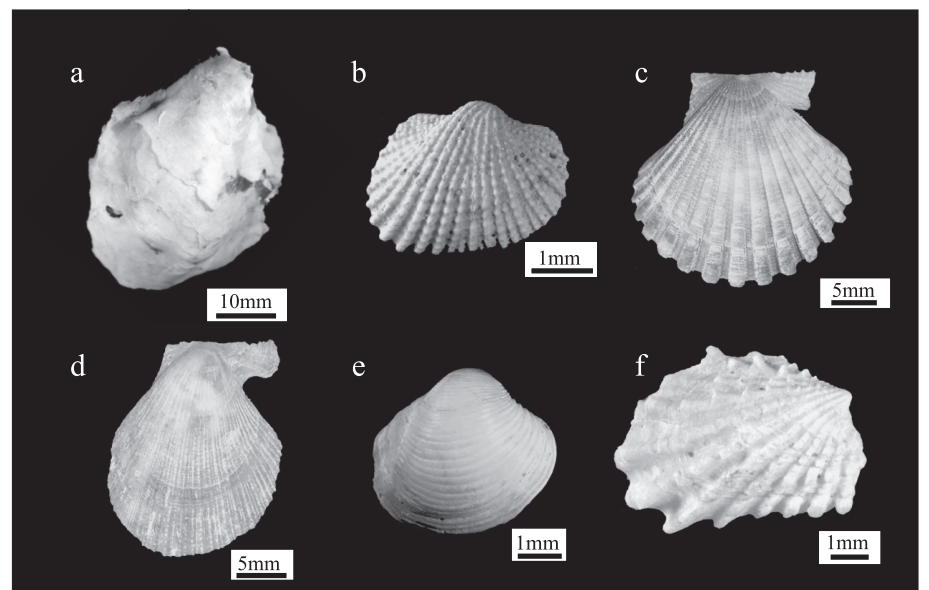
a:Neopycnodonte cochlear
b:Striarca fausta
c:Cryptopecten vesiculosus
$\mathrm{d}$ :Chlamys lemniscata
e:Varicorbula rotalis
$\mathrm{f}$ :Cardita leana

Fig. 5. Photograph of main six species in the Moeshima Shell Bed

jointed valves. No abrasion on the shells was discovered, so that the fossil group of Neopycnodonte cochlear was concluded as an autochthonous population.

\subsection{Support system for Neopycnodonte cochlear's population}

The community structure of the fossil assemblage in the Moeshima Shell Bed is very simple and is characterized by the pelagic species inhabiting at $100 \mathrm{~m}$ or greater depth. The deep-sea oyster Neopycnodonte cochlear occupies greater than $80 \%$ of the population in each of the bulk samples. This fact suggests that there was a certain ecological system for the habitat of the Neopycnodonte cochlear's population in the inner most part of the Kagoshima Bay.

To clarify reproductive conditions of the Neopycnodonte cochlear's population in the Moeshima Shell Bed, shell size frequency distribution of this species was examined. As a result, Neopycnodonte cochlear has a size frequency maximum consisting only juvenile shells (Fig. 6). In addition, it is noteworthy that the maximum-sized shells have only two annual growth rings. This means that new generation of the oysters were able to survive for only two years maximum in the innermost bay. These pieces of evidence suggest that Neopycnodonte cochlear's population in the Moeshima Shell Bed had no in-situ reproductive population and the population was supported by the larval supplement from the pelagic populations for the period of about 6,000 to 2,300 yrs BP. Neopycnodonte cochlear's larvae were advected from the pelagic realm and arrived at the inner most part of the bay and then grew up on the attached gravel there for one or two years. Most of them could not survive over two years. There are two conceivable conditions for the long-term accumulation of the juvenile shells: (1) hypoxia due to seasonal low oxygen condition with stratified water mass associated with its steep and deep bathymetry, and (2) acidification and hypoxia due to large flux of magmatic carbon dioxide as fumarolic discharge from the caldera bottom (Kamata et al., 1978; Horibe et al., 1980). The acidified bottom seawater has been considered to involve a unique fossil foraminiferal community in the innermost part of the bay (Oki, 1989). 

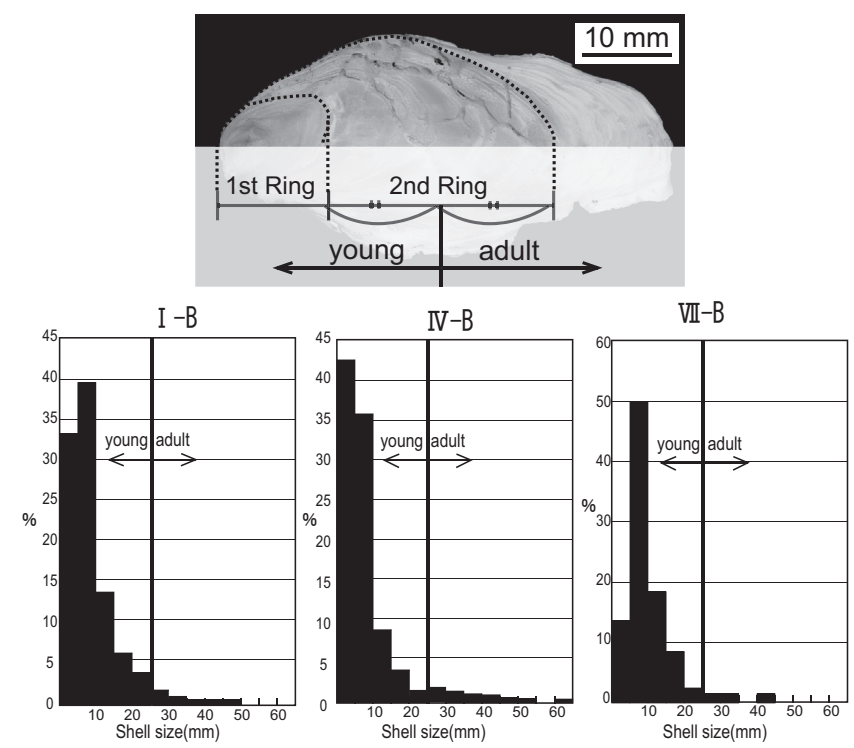

Fig. 6. Fossil shell size-frequency distribution of deepsea oyster, Neopycnodonte cochlear in three bulk samples ( I -B,IV-B, and VII-B). Bigger shells (one year old) than the center of second growth line are defined as adult in this study

\subsection{Paleo temperature estimation by oxygen isotopic composition}

Oxygen isotopic composition of calcium carbonate shells is a function of the ambient temperature and isotopic composition of the seawater at the time of the shell growth (e.g., Urey, 1947; Epstein et al., 1951). So far, oxygen isotopic composition of shell carbonates had been used as a useful geological thermometer. To estimate paleo-water temperature, several equations have been developed both experimentally and empirically (i.e., Epstein et al., 1951; Horibe and Oba, 1972; Oba, 1983 ; Grossman and $\mathrm{Ku}, 1986$ ).

The oxygen isotopic composition of the modern seawater $\left(\delta^{18} \mathrm{O}_{\text {SMOW }}=+0.1\right.$ to $+0.2 \%$ : depth $=$ $200 \mathrm{~m}$ ) examined herein is almost $0 \%$. This value is close to that of the present pelagic seawater of the northwestern Pacific off South Kyushu $\left(\delta^{18} \mathrm{O}_{\text {SMOW }}=-0.5\right.$ to $+0.5 \%$; Schmidt et al., 1999). The oxygen isotopic composition of pelagic seawater during the period of 6,000-2,000 yrs BP can be assumed to be similar to that of the modern pelagic seawater (Martinson et al., 1987; Shackleton, 2000; Waelbroeck et al., 2001). Therefore, the oxygen isotopic ratio of pelagic seawater may be constant through the last 6,000 years. The seawater mass in the innermost part of the Kagoshima Bay have been significantly affected by the pelagic seawater during that period of 6,000-2,000 yrs BP (see below for further details). Accordingly, oxygen isotopic composition of the seawater mass in the innermost part of the Kagoshima Bay during the last 6,000 yrs was provisionally assumed to be $0 \%$ in this study. On the other hand, the oxygen isotopic composition of seawater at 11,000 yrs BP was slightly higher than that of the modern pelagic seawater because of temporal sea level lowering in the Younger Dryas event. Therefore, oxygen isotopic composition of the pelagic seawater at $10,500 \mathrm{yrs}$ BP can be provisionally assumed to be $+0.6 \%$ vs. SMOW based on the difference the $\delta^{18} \mathrm{O}$ records of planktonic carbonate shells (Martinson et al., 1987).

In this study, the habitat temperatures ( $\mathrm{T}$ ) of fossil mollusks were estimated using the following two temperature scales described by Oba (1983) for calcite, and Grossman and $\mathrm{Ku}$ (1986) for aragonite: 
Calcite scale (Oba, 1983),

$$
\mathrm{T}\left({ }^{\circ} \mathrm{C}\right)=21.4-4.19\left(\delta^{18} \mathrm{O}_{\mathrm{PDB}} \text { calcite }-\delta^{18} \mathrm{O}_{\mathrm{SMOW}} \text { water }\right)+
$$

$$
0.05\left(\delta^{18}{ }_{\text {OPDB }} \text { calcite }-\delta^{18} \mathrm{O}_{\text {SMOW }} \text { water }\right)^{2}
$$

Aragonite scale (Grossman and $\mathrm{Ku}, 1986)$,

$$
\mathrm{T}\left({ }^{\circ} \mathrm{C}\right)=21.8-4.69\left(\delta^{18} \mathrm{O}_{\mathrm{PDB}} \text { aragonite }-\delta^{18} \mathrm{O}_{\mathrm{SMOW}} \text { water }\right)
$$

The results of oxygen isotopic composition of shell samples are shown in Table 2 together with the calculated paleo-water temperature according to the above equations. The oxygen isotopic compositions $\left(\delta^{18} \mathrm{O}_{\mathrm{PDB}}=+0.3\right.$ to $+1.1 \%$ ) of the shell samples collected from the Moeshima Shell Bed are slightly lighter than those from the underlying Moeshima Silt Bed $\left(\delta^{18} \mathrm{O}_{\mathrm{PDB}}=+1.7 \%\right)$. The calculated seawater temperature obtained from the modern, Saccostrea echinata and Monodonta labio obtained from the shallow coastal area, was $26^{\circ} \mathrm{C}$, whose value is nearly comparable with the present annual average temperature of their habitat (about $25^{\circ} \mathrm{C}$; Oki, 1989). Thus, the results are consistent. The caliculated paleo-water temperatures of the fossil molluscan habitats based on both scales were clearly lower than that of the present samples, and were in good agreement with each other except for the Paphia sample obtained from the Moeshima Shell Bed. Thus, the fossil communities of the Moeshima Shell Bed indicate a inhabitant of low water temperature zone under a significant depth of seafloor.

The values of the paleo-water temperatures in the period of about 6,000-2,300 yrs BP were applied to the median values of vertical distribution of the modern water temperatures measured in the innermost part of the Kagoshima Bay (Oki, 1989). The oxygen isotopic analysis of the fossil shells were carried out without taking subdivided seasonal samples. In other words, the measured oxygen isotope ratios represent the median values including seasonal variation of isotopic ratios as well as the present samples described the above. Therefore, the paleo-water temperatures calculated from the oxygen isotopic ratios represent the median of seasonal temperature variation. The calculated temperature, ranging from 17.6 to $20.5^{\circ} \mathrm{C}$, suggests that the fossil community in the Moeshima Shell Bed inhabit at least deeper than about $40 \mathrm{~m}$ below the sea surface (Fig. 7). It is concluded, therefore, the habitat depths of the major three species, Neopycnodonte cochlear, Cryptopecten cesiculosus and Zeuxi hayashii were estimated to be around $50 \mathrm{~m}$ or deeper (Fig. 7). This result does not contradict with the results of the fossil shell community analysis.

Table 2. Oxygen isotopic compositions of carbonate in different crystal system shell samples collected from the Moeshima Silt Bed and Moeshima Shell Bed, the present Kagoshima Bay, and the calculated temperatures.

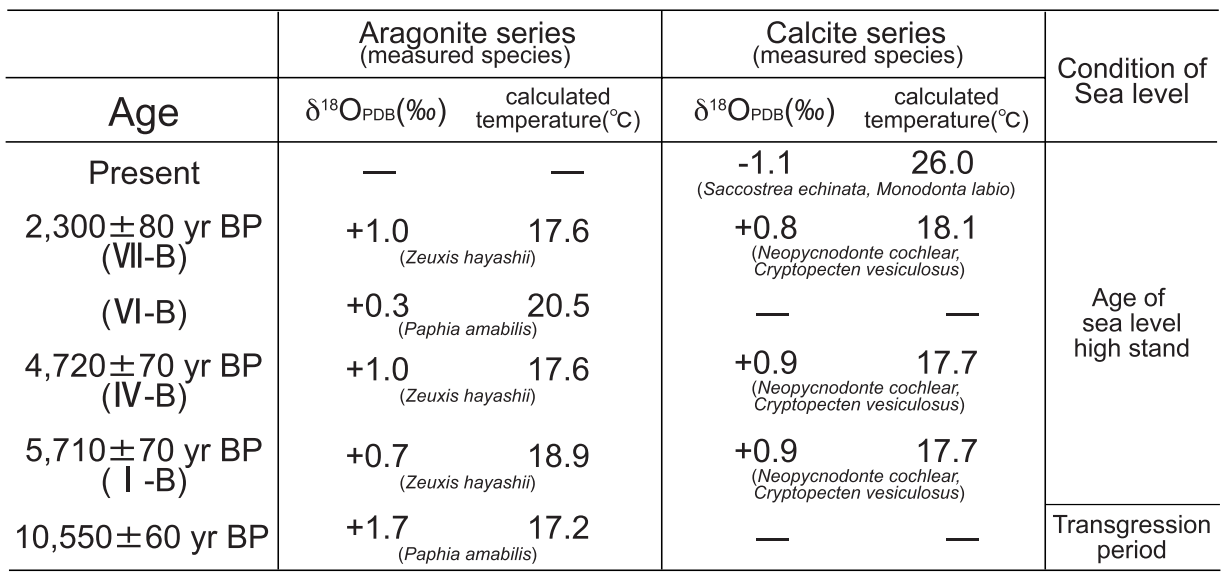




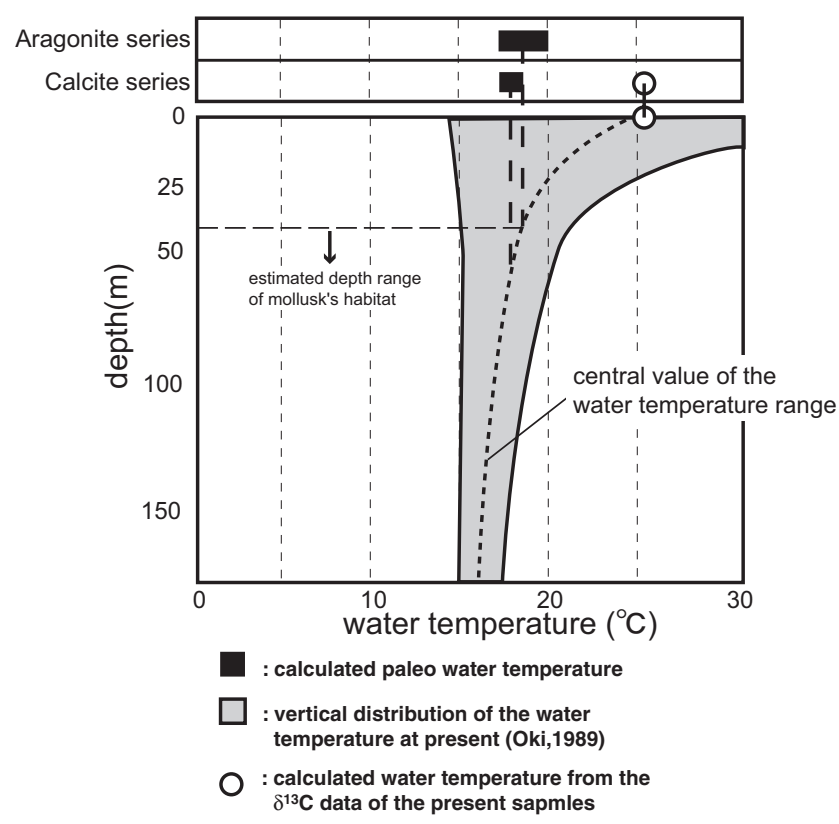

Fig. 7. Estimated depth range of mollusk's habitat based on the paleo-temperature calculated by the oxygen isotopic ratio in calcite and aragonite series of Table 3.

Although the $\delta^{18} \mathrm{O}$ value of the fossils from the Moeshima Silt Bed is clearly higher than those of the other fossil samples of different horizons, the estimated paleo-water temperature $\left(17.2^{\circ} \mathrm{C}\right)$ is slightly lower than the estimated temperature oh the Moeshima Shell Bed $\left(\geq 17.6^{\circ} \mathrm{C}\right)$. The relatively high $\delta^{18} \mathrm{O}$ value seems to be attributed to the slightly high $\delta^{18} \mathrm{O}$ value of seawater at $11,000 \mathrm{yrs} \mathrm{BP}$. Based on the calculated paleo-water temperature, this species also appears to have inhabited in the significant water depth of the sea floor.

\subsection{Carbon isotopic profiles of shell carbonate during the past 11,000 years}

The results of carbon isotopic ratios of shell carbonate are shown in Table 3. The carbon isotopic ratios for the shell samples collected from the Moeshima Shell Bed $\left(\delta^{13} \mathrm{C}_{\mathrm{PDB}}=+1.0\right.$ to $+2.5 \%$ ) are heavier than those of the shell samples collected from the Moeshima Silt Bed $\left(\delta^{13} \mathrm{C}_{\mathrm{PDB}}=+0.1 \%\right.$ o and the modern shell samples $\left(\delta^{13} \mathrm{C}_{\mathrm{PDB}}=-0.2\right.$ to $\left.+0.4 \%\right)$. The carbon isotopic ratios of shell carbonate from each species were slightly different with respect to each feeding style. The suspended particle feeders tend to be rich in $\delta^{13} \mathrm{C}$ throughout the whole period.

Carbon isotopic composition of shell carbonate depends primarily on bicarbonate ion dissolved in the ambient sea water. The present carbon isotopic ratios of dissolved inorganic carbonate of surface sea water around Japan are about $+1.5 \%$ (Inoue et al., 1977). Furthermore, the carbon isotopic ratio of dissolved inorganic carbonate of surface water since about 7,000 yrs BP is also estimated as about $+1.5 \%$ (Ijiri et al., 2005). In comparison, carbon isotope ratio of dissolved inorganic and organic carbon from land is markedly lighter $\left(-33 \%<\delta^{13} \mathrm{C}_{\mathrm{PDB}}<-10 \%\right.$ : Denies, 1980). Therefore, the carbon isotopic ratios of carbonate in the sea water of the inner bay may be lighter than the pelagic value because the contribution of isotopic light carbon from the land is higher than that of the bay mouth, mentioned as follows. The variation shows the carbon isotopic 
Table 3. Carbon isotopic compositions in different feeding types of the molluscan shell samples collected from the Moeshima Silt Bed and Moeshima Shell Bed and the present Kagoshima Bay.

\begin{tabular}{|c|c|c|c|c|}
\hline & \multicolumn{3}{|c|}{$\delta^{13} C_{\text {PDB }}(\% 0)$} & \multirow{2}{*}{$\begin{array}{l}\text { Condition of } \\
\text { Sea level }\end{array}$} \\
\hline Age & $\begin{array}{c}\text { scavenger } \\
\text { (measured species) }\end{array}$ & $\begin{array}{c}\text { plankton feeder } \\
\text { (measured species) }\end{array}$ & $\begin{array}{c}\text { suspended particle feeder } \\
\text { (measured species) }\end{array}$ & \\
\hline Present & - & $\begin{array}{c}-0.2 \\
\text { (Monodonta labio) }\end{array}$ & $\begin{array}{c}+0.4 \\
\text { (Saccostrea echinata) }\end{array}$ & \multirow{5}{*}{$\begin{array}{l}\text { Age of } \\
\text { sea level } \\
\text { high stand }\end{array}$} \\
\hline $2,300 \pm 80$ yr BP & $\begin{array}{l}+1.7 \\
\text { (Zeuxis hayashii) }\end{array}$ & $\begin{array}{l}+1.7 \\
\text { (Cryptopecten } \\
\text { vesiculosus) }\end{array}$ & $\begin{array}{l}+2.4 \\
\text { (Neopycnodonte cochlear) }\end{array}$ & \\
\hline (VI-B) & - & $\begin{array}{l}+1.0 \\
\text { (Paphia amabilis) }\end{array}$ & - & \\
\hline$\underset{(\mathrm{IV}-\mathrm{B})}{4,720 \pm 70 \mathrm{yr} B P}$ & $\stackrel{+1.7}{\text { (Zeuxis hayashii) }}$ & $\begin{array}{c}+1.8 \\
\text { (Cryptopecten } \\
\text { vesiculosus) }\end{array}$ & $\begin{array}{l}+2.5 \\
\text { (Neopycnodonte cochlear) }\end{array}$ & \\
\hline $5,710 \pm 70$ yr BP & $\begin{array}{l}+1.4 \\
\text { (Zeuxis hayashil) }\end{array}$ & $\begin{array}{l}+1.7 \\
\text { (Cryptopecten } \\
\text { vesiculosus) }\end{array}$ & $\begin{array}{c}+2.5 \\
\text { (Neopycnodonte cochlear) }\end{array}$ & \\
\hline $10,550 \pm 60$ yr BP & - & $\begin{array}{l}+0.1 \\
\text { (Paphia amabilis) }\end{array}$ & - & $\begin{array}{c}\text { Transgression } \\
\text { period }\end{array}$ \\
\hline
\end{tabular}

Table 4. Carbon isotopic compositions of inorganic carbonate taken from six locations in the present Kagoshima Bay.

\begin{tabular}{c|c}
\hline sample & $\delta^{13} \mathrm{C}_{\mathrm{PDB}}(\% \mathrm{o})$ \\
\hline $\mathrm{W} 1$ & 0.0 \\
$\mathrm{~W} 2$ & -0.8 \\
$\mathrm{~W} 3$ & -2.0 \\
$\mathrm{~W} 4$ & -2.3 \\
$\mathrm{~W} 5$ & 0.0 \\
$\mathrm{~W} 6$ & +0.3 \\
\hline
\end{tabular}

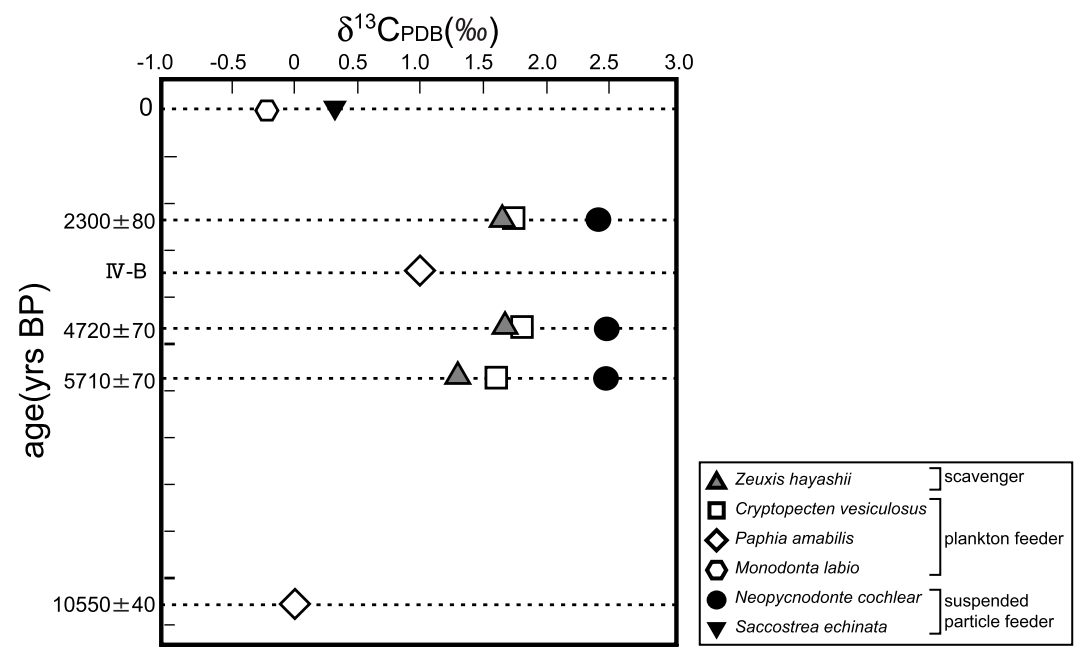

Fig. 8. Changes of carbon isotopic composition of fossil shells from 10,550 yr BP to the present in the innermost of Kagoshima Bay. 
ratios of dissolved inorganic carbon in the surface waters collected from several locations in the Kagoshima Bay (Table 4; Fig. 8). The carbon isotopic ratios of dissolved inorganic carbonate of surface water change into lighter values gradually from the bay mouth to the innermost bay (W1 to W4). Furthermore, the carbon isotopic compositions of the samples (W5, W6) from the water column are also definitely lighter than those of pelagic waters $(+1.5 \%)$. Therefore, it seems that the carbon isotopic composition of shell carbonate shows the extensive influence of pelagic water mass.

As a result, $\delta^{13} \mathrm{C}_{\mathrm{PDB}}$ during the period of about $6,000-2,300 \mathrm{yrs} \mathrm{BP}(+1.0$ to $+2.5 \%)$ indicates that the bay water was almost the same as the surface water of the pelagic sea, while the isotopic ratios of about $11,000 \mathrm{yrs} \mathrm{BP}(+0.1 \%)$ and the modern shells $(-0.2$ to $+0.4 \%)$ indicate markedly lighter values (Table 3). In other words, the influence of the pelagic seawater mass was small at about 11,000 yrs BP. Then the influence of the pelagic seawater became extremely significant during the period of about 6,000-2,300 yrs BP in the innermost part of the bay. Subsequently, the pelagic seawater influence in the innermost part of the bay became small again at present.

On the other hand, the feeding styles also affect the carbon isotopic compositions of shell carbonate. It has been understood as "vital effect" caused by different nutrition and metabolism among species (Spero and Lea, 1993; Ortiz et al., 1996; Khim et al., 2001), so it must be considered as another plausible cause for the heavy isotopic ratios during the period of about 6,000-2,300 yrs BP. To clarify this effect, shell samples of the same species, Paphia amabilis, collected from both horizons of 11,000 yrs BP and 6,000 to 2,300 yrs BP were measured. As a result, Paphia amabilis of 6,000 to $2,300 \mathrm{yrs} \mathrm{BP}$ was markedly heavier than the values of 11,000 yrs BP in carbon isotopic ratio of shell carbonate. It may suggest that the vital effect can be ignored. Therefore, it is concluded that the influence of the pelagic seawater is the most important factor for the heavy ratios during the period of about 6,000-2,000 yrs BP.

\subsection{Changes of water mass condition in the innermost part of the Kagoshima Bay during the past 11,000 years}

It is possible to estimate the following changes of the water mass environment for the inner most part of the Kagoshima Bay (Fig. 9). The analytical results of fossil shell assemblage and carbon

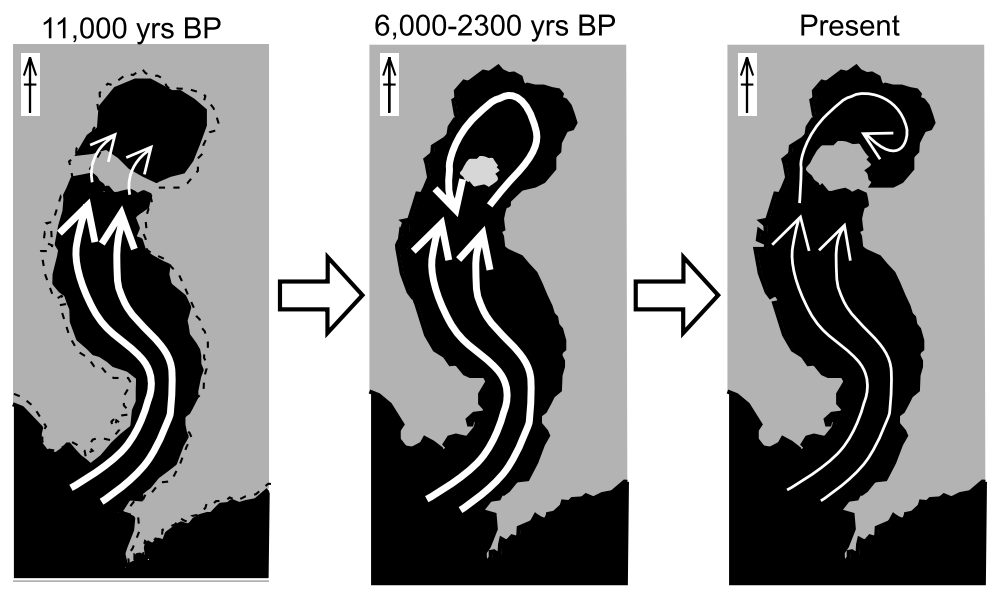

Fig. 9. Schematic diagrams showing an influence and change of outer seawater mass (Kuroshio) to the innermost Kagoshima Bay area. Thickness of lines shows degree of the influence. Broken line is the present shore line. The present situation (right figure) was illustrated based on data of Oki (1989) 
isotope indicate that the innermost area of the Kagoshima Bay had been filled with pelagic seawater for about 9,000 years during the period of the marine condition from the beginning at ca. 11,000 yrs $\mathrm{BP}$ to the ending at ca. 2,300 yrs BP. The influence of the pelagic seawater was not significant since ca. 11,000 yrs BP, but it became the maximum during the period from 6,000 to 2,300 yrs BP (Fig. 9). The inflow of pelagic seawater is backed up by the prosperity of the contemporaneous pelagic mollusks. Since the colonies were exclusive of adults, and the colonies must have been sustained by a significant number of larvae supply from mother populations outside of the bay.

It is now necessary to pursue the presence of a pump that supplies the pelagic seawater into the inside of the bay. The Kuroshio Current is the most significant available candidate. According to Matsushima (1989), the strength of Kuroshio Current was at the maximum, and distribution of subtropical molluscan species extended to northward significantly along the southwestern coast of Japan during that period. The Kuroshio Current is the continuing flow of the North Equatorial Current, of the equatorial Pacific, and it flows northward along the east cost of the Philippines and Taiwan and along the west side of the Pacific Ocean. The current flows into the East China Sea off the east coast of Taiwan, and then goes to the Pacific Ocean again in the vicinity of the Kagoshima Bay. A part of the Kuroshio Current water mass is transported into the Kagoshima Bay. Satellite images of bay surface temperature in the Kagoshima Bay prove the existence of the warm waters (Oki, 2000). This fact suggests that the Kuroshio Current has been attributed as the pelagic seawater pump.

After about 2,300 yrs BP, which corresponds to the top horizon of the Moeshima Shell Bed, pelagic species disappeared. Instead of the disappearance of the pelagic species, inner bay species appeared in the bay. As possible causes of the marked change in fossil community in the Kagoshima Bay, the decreasing in strength of the Kuroshio Current and the growth of the Sakurajima volcano island must be discussed (Fig. 9). The latter also disrupted the inflow of pelagic seawater. However, the growth of the volcanic island has no direct influence on the extinction event because the extinction of pelagic species is not limited to the innermost part, but it occurred in the entire bay. Therefore, the change of molluscan species in the Kagoshima Bay seems to reflect a long-term change of the strength of the Kuroshio Current (Matsushima, 1989). The marked decline of pelagic seawater compelled to stop the larval recruitment to the colonies in the bay, causing the extinction.

\section{Conclusions}

Assemblage analysis of fossil shells from Shinjima Island in Kagosima Prfecture was carried out. The results were examined with the oxygen and carbon stable isotopic composition of the fossil molluscan shell carbonates. As the results, following conclusions are obtained.

1. The innermost part of the Kagoshima Bay changed from non-marine into seawater condition at $11,000 \mathrm{yrs}$ BP. The pelagic condition appeared directly in the bay without involving an intermediate inner bay condition at that time or preceding to that time. This is apparent from the oldest and continuous fossil shell group is represented by only pelagic species.

2. The most concentrated shell layer (the Moeshima Shell Bed) was formed during the period from about 6,000 to 2,300 yrs BP. The fossil shell assemblage in the Moeshima Shell Bed mostly consists of deep pelagic species inhabiting deeper than $100 \mathrm{~m}$ in water depth.

3. The most dominant species ( $80 \%$ or greater) of the fossil shell assemblage in the Moeshima Shell Bed was a deep-sea oyster, Neopycnodonte cochlear. The population of the species was composed of mostly juvenile shells in growing stage and there were almost no adult shells in the assemblage. The autochthonity of the fossil assemblage is high. Therefore, it seems that there is no reproductive population sustained in the Kagoshima Bay, and a large quantity of larvae of 
these species had been advanced from the mother populations located outside of the Kagoshima Bay into the innermost bay area. The adveced larvae set on pumice granule substrates at the sea floor, and they grew up to juveniles for two years until their natural death.

4. Paleo-water temperature was reconstructed based on the oxygen isotopic ratios of aragonite and calcite series in shell carbonate from the Moeshima Shell Bed. The paleo depth of mollusks was estimated around $50 \mathrm{~m}$ or deeper based on the relationship between the water temperature and water depth in the modern Kagoshima Bay. This result is consistent with the results from species composition of the fossil shell assemblage in the Moeshima Shell Bed.

5. Carbon stable isotopic ratios in the inner bay water are generally lighter than those in the pelagic one. Carbon stable isotopic ratios of fossil shell carbonate collected from the Moeshima and Shell Bed were heavier than those of the modern water and shells in the inner most part of the Kagoshima Bay. However, the isotopic ratios in the Moeshima Silt Bed were similar to those of the modern seawater. This fact suggests that pelagic seawater was diluted by the inner bay water when the marine condition began at about 11,000 yrs BP when the pelagic seawater became the most influential. The influence of the pelagic waters was kept for the period of about 6,000-2,300 yrs BP, but it became weak again after 2,300 yrs BP. This interpretation is conformable with the vertical change in the fossil molluscan assemblages. The most considerable origin of pelagic seawater is a part of the Kuroshio Current. The strength of the Kuroshio Current governed the changes of seawater conditions pertinent to the biota dwelling in the inner most area of the Kagoshima Bay.

\section{Acknowledgements}

We express our gratitude to Professor Minoru Kusakabe and Ms. Tazue Nogi for providing laboratory facility in isotopic analysis at the Institute for the Earth's Interior, Okayama University, and Associate professor Urumu Tsunogai and Dr. Akira Ijiri, Hokkaido University, for measuring carbon isotopic study. We are also indebted to Professor Chitoshi Mizota, Iwate University, Mr. Brice Loose, Colombia University, Dr. Takashi Sakai and Professor Kozo Takahashi of Kyushu University, for their reviewing drafts of the manuscript and providing very useful comments, and Ms. Noriko Watanabe for her assistance in the field. We express our gratitude to the reviewers for their help in improving our English of the manuscript. This research was supported in part by a grant from Takachiho Scholarship Fund of Kyushu University.

\section{References}

Aramaki, S. (1984) Formation of Aira Caldera, southern Kyushu, 22,000 years ago. J. Geophys. Res., 89, 8485-8501.

Craig, H. (1957) Isotopic standards for carbon and oxygen and correction factors for massspectrometric analysis of carbon dioxide. Geochim. Cosmochim. Acta, 12, 133-149.

Deines, P. (1980) The isotopic composition of reduced organic carbon. In, Handbook of Environmental Isotope Geochemistry, vol. 1, P. Fritz and J.Ch. Fontes eds., Elsevier, 329-434.

Epstein, S., Buchsbaum, R., Lowenstam, H. A., and Urey, H. C. (1953) Revised carbonate-water isotopic temperature scale. Bull. Geol. Soc. Amer., 64, 1316-1326.

Epstein, S., and Mayeda, T. (1953) Variation of ${ }^{18} \mathrm{O}$ content of waters from natural sources. Geochimica et Cosmochimica Acta, 4, 5, 213-224.

Grossman, E.L. and Ku, T-L. (1986) Oxygen and carbon isotope fractionation in biogenic aragonite: 
temperature effects. Chem. Geo., 59, 59-74

Higo, S., Callomon, P., and Goto, Y. (1999) Catalogue and bibliography of the marine shell-bearing mollusca in Japan. Elle Scientific Publications, Osaka, 749pp.

Hirata, K. (1964) Moeshima Shell Bed. In, Nature in Kagoshima, Kagoshima science education society, 235-244 (in Japanese).

Horibe, Y., and Oba, T. (1972) Temperature scales of aragonite-water and calcite-water systems. Fossils (Palaeontological Society of Japan). 23 • 24, $69-79$ (in Japanese).

Horibe, Y., Gamo, T., and Baba, Y. (1980) Estimation of carbon dioxide flux from submarine volcano in Kagoshima Bay, Japan. In Isotope Marine Chemistry, Uchida Rokakuho, Tokyo, pp. 327-337.

Ijiri, A., Wang, L., Oba, T., Kawahata, H, Huang, C-Y., and Huang, C-Y. (2005) Paleoenvironmental changes in the northern area of the East China Sea during the past 42,000 years. Palaeogeography, Palaeoclimatology, Palaeoecology, 219, 239-261

Inoue, H., Sugimura, Y., and Fshimi, K. (1987) $\mathrm{pCO}_{2}$ and $\delta^{13} \mathrm{C}$ in the air and surface sea water in the western North Pacific. Tellus, 39B, 228-242.

Kamata, M., Yonehara, N., Sakamoto, H., and Ohnishi, T. (1978) Distribution of the trace elements and the circulation process of sea water in the inner bay sea water - an example at the Kagoshima Bay. Collected Reports of Special Project Research, "Preservation of Marine Environment" (Takahashi, A. ed.) 49-54 (in Japanese).

Kameyama, S., Shimoyama, S., Miyabe S., Miyata, Y., Sugiyama, T., Iwano, H., Danhara, T., Endo K., and Matsukuma, A. (2005) Stratigraphy and ages of Aira Caldera deposits in Shinjima (Moeshima), Kagoshima Pref., West Japan. Quaternary Research, 44, 15-29 (in Japanese).

Kano, K., Yamamoto, T., and Ono, K. (1996) Subaqueous eruption and emplacement of the Shinjima Pumice, Shinjima (Moeshima) island, Kagoshima Bay, SW Japan. J. Volcanol. Geotherm. Res., 71, 187-206.

Khim, B.K., Krantz, D.E., and Brigham-Grette, J. (2001) Stable isotope profiles of Last Interglacia (Pelukian Transgression) mollusks and paleoclimate implications in the Bering Strait Region. Quaternary Science Reviews, 20, 463-483.

Kino, Y., Teraoka, Y., Kinugasa, Y., and Isobe, K. (1976) Geological study of the northeast Sakurajima and Shinjima and other An-ei islets. In : Special research report on the coast collapse of the Shinjima Island, Kagoshima Bay. Sci. Technol. Agency Japan, 29-54 (in Japanese).

Kuwashiro, I. and the geographical seminar of Kagoshima junior college (1970) Study of the Aira caldera No.2, The birth, geographical and geological features and coastal erosion of Shinjima. Chiran Culture, 7, 65-86 (in Japanese).

Machida, H, Ota, Y., Kawana, T., Moriwaki, H., and Nagaoka, S. (2003) Japanese topography 7. Kyushu and Nansei islands, University of Tokyo Press, 355 pp. (in Japanese).

Martinson, D. G., Pisias, N. G., Hays, J. D., Imbrie, J., Moore, T. C., and Shackleton, N. J. (1987) Age dating and the orbital theory of the ice ages: development of a high-resolution 0 to 300000 year chronostratigraphy. Quaternary Research 27, 1-29.

Matsushima, Y. (1989) changes of the paleoenvironment basis of the mollusks: Especially, in Jomon period. What did the new research methods bring to the archeology?, 10-31 (in Japanese).

Matsumoto, T. (1943) The four gigantic caldera volcanoes of Kyushu. Japanese journal of geology and geography, 19, 57p.

Oba, T. (1983) Paleoenvironment of the Sea of Japan since the last glaciation. Chikyu (Monthly, the Earth), 5, 37-46 (in Japanese).

Oki, K. (1989) Ecological analysis of benthonic foraminifera in the Kagoshima Bay, South Kyushu, Japan. South Pacific Study, Kagoshima Univ. Res. Center S. Pac., 10(1), 1-191.

Oki, K. (2000) The mysteries of Kagoshima Bay. Shuneido Shuppan, 223 pp (in Japanese). 
Okuno, M., Matsushima, Y., Nagaoka, S., Moriwaki, H., Arai, F., and Nakamura, T. (1998) AMS radiocarbon dating of shell fossil (Neopycnodonte musashiana) in the Moeshima shell bed. Kagoshima Bay, SW Japan, Fukuoka University scientific reports collection, 28, 123-128 (in Japanese).

Ortiz, J. D., Mix, A.C., Rugh, W Watkins, J. M., and Collier, R. W. (1996) Deep-dwelling planktonic foraminifera of the northeastern Pacific Ocean reveal environmental control of oxygen and carbon isotopic disequilibria. Geochimica et Cosmochimica Acta, 60 (22), 45094523.

Raup, D. M., and Stanley, S. M. (1978) Principles of Paleontology. W.H. Freeman, San Francisco, 2nd edition, 481pp.

Schmidt, G. A., Bigg, G. R., and Rohling E. J. (1999) Global Seawater Oxygen-18 Database. http://www.giss.nasa.gov/data/o18data/

Shackleton, N. J., Imbrie, J., and Hall, M.A. (1983) Oxygen and carbon isotope record of East Pacific core V19-30: implications for the formation of deep water in late Pleistocene North Atlantic. Earth and Planetary Science Letters, 65, 233-244.

Shackleton, N. J. (2000) The 100,000-year Ice-Age cycle identified and found to lag temperature, carbon dioxide, and orbital eccentricity. Science 289, 1897-1902.

Shikama, T. (1955) Stratigraphical position of Moeshima Shell Bed, Kagoshima Pref.. The Journal of the Geological Society of Japan, 61, 723 (in Japanese).

Shuto, T. (1962) Investigation of Holocene stratum in Kyushu: The foundation of the comparison (Studies of historical geology of Holocene stratum in Kyushu-II ). The Journal of the Geological Society of Japan, 68, 301-312 (in Japanese).

Spero, H. J., and Lea, D. W. (1993) Intraspecific stable isotope variability in the planktonic foraminifer Globigarinoides sacculifer: results from laboratory experiments. Marine Micropaleontology, 22, 221-34.

Urey, H. C. (1947) The thermodynamic properties of isotopic substances. J. Chem. Soc., 1, 562-581.

Waelbroeck, C., Duplessy, J. C., Michel, E., Labeyrie, L., Paillard, D., and Duprat, J. (2001) The timing of the last deglaciation in North Atlantic climate records. Nature, 412, 724-727.

Yamaguchi, K. (1915) Islands which are close to Sakurajima. Journal of geography, 27, 18-43 (in Japanese).

Yamanaka T., Mizota C., Murae T., and Hashimoto J. (1999) A currently forming petroleum associated with hydrothermal mineralization in a submarine caldera, Kagoshima Bay, Japan. Geochem. J. 33, 355-367. 